\title{
PENYALAHGUNAAN OBAT BATUK ADITUSIN DI KALANGAN REMAJA
}

\author{
Remi Aldi, S.Sos dan Abdul Munir, S.Sos., M.Krim
}

\begin{abstract}
Abuse of Aditusine cough medicine by adolescents in Belilas Village, Kec. Seberida, Kab. Inhu (Riau), as a social phenomenon that grows in the midst of people's lives. By using the Differential Association theory approach and Techniques of Neutralization as an analytical knife and a qualitative approach as the method, this research finds a conclusion; there has been a shift in the use of drugs from previously illegal drugs (shabu, marijuana, etc.) to legal drugs (Aditusine cough medicine), as a way to avoid prosecution from both a legal and social perspective.
\end{abstract}

Keywords: Abuse, Aditusin, Dextromethorphan Hd, Adolescents.

\section{Latar Belakang}

Tingginya peredaran narkotika di Indonesia saat ini semakin membuktikan Indonesia tidak hanya sebagai tempat persinggahan (transit) melainkan sebagai tempat sasaran atau pasar bagi pelaku pengedaran narkotika jaringan internasional (Prayuda \& Syafri Harto : 2020). Massifnya pengguna narkotika tanpa memandang status sosial dan usia, tentu menjadi preseden buruk bagi kedaulatan bangsa kita. Tidak hanya kerugian dari sisi ekonomi dialami bangsa ini, degradasi mental dan moral masyarakat, serta pupusnya tunas masa depan bangsa yang ditentukan oleh generasi muda, menjadi sangat dikhawatirkan karena persoalan narkotika ini. Maka tidaklah berlebihan sekiranya menempatkan isu tentang penyalahgunaan obat-obatan dikalangan generasi muda saat ini, sejatinya wajib menjadi bagian dari agenda utama Nasional Pemerintah yang segera ditindaklanjuti secara serius dan terukur dalam penanggulangannya.

Survei yang dilakukan BNN bersama LIPI, mendapati angka 2,3 juta pelajar dan mahasiswa diseluruh daerah Indonesia pernah bersentuhan dengan narkotika. (www.cnnindonesia.com). Data survei BNN dan LIPI tersebut, tentu hanya sebatas gambaran permukaan atau perwakilan dari jumlah total populasi pengguna dikalangan generasi muda yang ada, dan masih sangat memungkinkan fenomena gunung es berlaku dalam masalah ini, sehingga angka pengguna 
yang belum terdeteksi jauh lebih besar dibanding data yang ditemukan oleh BNN dan LIPI di atas.

Ditengah giat dan gencarnya Pemerintah melakukan upaya penanggulangan peredaran narkotika baik melalui aparat kepolisisan dan BNN dibantu pula seluruh stake holder lain yang fokus dibidang penanggulangan narkotika ini, namun dirasa masih belum menunjukkan hasil memuaskan menyangkut penggurangan di level peredaran maupun penggunaan narkotika di Indonesia. Persoalan lain yang menambah pelik dari upaya penanggulangan penggunaan obat-obatan di kalangan remaja dewasa ini adalah, munculnya fenomena dilapangan menyangkut peralihan pola penggunaan dari sisi jenis obatan-obatan yang sebelumya terlarang (illegal) seperti ; sabu, ekstasi dan sebagainya, kepada jenis obatobatan yang bersifat legal yang dapat diperoleh dengan cara mudah baik melaui apotik obat atau dipesan secara online. Katakanlah seperti obat batuk Aditusin, hydrobromide yang kegunaannya untuk mengobati batuk disertai dengan pilek dan alergi (dalam, www.klikdokter.com).

Berbeda dengan obat batuk lainnya yang hanya bekerja pada saluran pernapasan, kandungan dextromethorphan yang terdapat dalam obat Aditusin, bekerja pada otak dan di sistem saraf pusat dengan meningkatkan ambang rangsang refleks batuk (www.sehatq.com). Bila dikonsumsi dalam dosis yang sesuai, maka dapat berkhasiat menekan batuk dan menurunkan demam. Sebaliknya jika dikonsumsi dalam jumlah berlebih, efek dextromethorphan dapat menyerupai obatobatan terlarang, seperti phencyclidine dan ketamin (obat bius yang digunakan untuk keperluan operasi dalam dunia medis) dimana dapat menyebabkan halusinasi dan euforia (dalam, www.sehatq.com).

Fenomena penyalahgunaan obat batuk aditusin secara berlebih oleh anakanak remaja dengan tujuan untuk mendapatkan sensasi mabuk atau nge-flay, tampaknya telah menjadi alternatif baru bagi mereka pengguna untuk mengantikan atau menggeser dari penggunaan obatobatan terlarang seperti ; sabu, ekstasi, putaw, ineks dan sejenisnya. Situasi inilah yang menjadi tambah pelik dalam mengatasi masalah penyalahgunaan obatobatan dikalangan remaja nantinya, disaat mana obat batuk seperti aditusin dapat bebas dibeli tanpa resep dokter, namun disisi lain peluang untuk disalahgunakan sulit dikontrol dikarenakan obat batuk seperti aditusin tidak dalam kategori obatobatan terlarang.

\section{Kerangka Konseptual}

\section{a. Penyalahgunaan Obat-Obatan}


Penyalahgunaan obat-obatan apapun jenisnya di luar kepentingan medis adalah merupakan perbuatan buruk. Dalam konteks remaja, maka dapat dikatakan sebagai bentuk kenakalan remaja yang bersifat khusus. Terdapat faktor yang amad konpleks bagi para pengguna sehingga mereka dapat terjebak dalam perbuatan tersebut. Merujuk hasil studi yang dilakukan Amanda, dkk (2017), ada beragam faktor hubungan remaja terlibat dalam penggunaan obat terlarang diantaranya :

1. Gaya

2. Hubungan dekat kelompok kekerabatan

3. Rasa ingin tahu

4. Ikut-ikutan

5. Ingin terlepas dari rasa stres

6. Merasa Hebat

7. Menghilangkan Rasa Penat dan Bosan

8. Mencari Tantangan atau Kegiatan Beresiko

9. Merasa Dewasa.

\section{b. Aditusin}

Merupakan obat yang diperuntukkan mengatasi gangguan batuk yang disertai dengan pilek dan alergi. Setidaknya terdapat dua kandungan zat didalamnya chlorphenamine maleate dan dextromethorphan hydrobromide (dalam, www.klikdokter.com).

Untuk pemakaian obat batuk aditusin pada tingkat tinggi, maka dipastikan dapat mengakibatkan peningkatan risiko diantaranya : hiperpireksia, halusinasi, eksitasi kasar atau koma (dalam, www.klikdokter.com).

\section{c. Dextromethorphan}

Dextromethorphan hydrobromide adalah bagian zat dalam kandungan obat batuk aditusin. Merupakan obat batuk golongan antitusif atau penekan batuk yang umum digunakan untuk mengobati batuk akibat pilek dan flu, bekerja di sistem saraf pusat dengan meningkatkan ambang rangsang refleks batuk. Pada dosis tinggi, efeknya dapat menyerupai obatobatan terlarang yang dapat menyebabkan halusinasi dan euforia (dalam, www.sehatq.com).

Terdapat beberapa tahap keracunan dextromethorphan hydrobromide tergantung pada seberapa banyak obat yang diminum. Efek yang umum terjadi adalah kepala menjadi ringan hingga ada sensasi (keluar dari tubuh), terjadi halusinasi, paranoia, dan perilaku agresif. Efek tersebut dapat bertahan dari 30 menit hingga 6 jam setelah obat diminum (dalam, www.sehatq.com). 
Dikarenakan banyaknya kasus penyalahgunaan dextromethorphan hydrobromide yang terjadi, pada tahun 2018 lalu, akhirnya BPOM sebagai lembaga yang berwenang terhadap regulasi peredaran obat di Indonesia, mengeluarkan Peraturan BPOM nomor 28 tahun 2018 tentang Pedoman Pengelolaan Obat-Obat Tertentu yang Sering Disalahgunakan. Pada saat itu dextromethorphan hydrobromide resmi masuk dalam golongan OOT (Obat-Obat Tertentu) termasuk lima obat lain yakni ; tramadol, triheksifenidil, klorpromazin, amitriptilin, dan haloperidol.

\section{d. Remaja}

Remaja merupakan masa dimana peralihan dari masa anak-anak ke masa dewasa, yang telah meliputi semua perkembangan yang dialami sebagai persiapan memasuki masa dewasa. Perubahan perkembangan tersebut meliputi aspek fisik, psikis dan psikososial. Masa remaja merupakan salah satu periode dari perkembangan manusia.

Menurut Monks (2008) remaja merupakan masa transisi dari anak-anak hingga dewasa, Fase remaja tersebut mencerminkan cara berfikir remaja masih dalam koridor berpikir konkret, kondisi ini disebabkan pada masa ini terjadi suatu proses pendewasaan pada diri remaja. Masa tersebut berlangsung dari usia 12 sampai 21 tahun, dengan pembagian sebagai berikut :

1. Masa remaja awal (Early adolescent) umur 12-15 tahun,

2. Masa remaja pertengahan (middle adolescent) umur 15-18 tahun,

3. Remaja terakhir umur (late adolescent) 18-21 tahun.

\section{Landasan Teori}

\section{a. Differential Association / Belajar Kejahatan.}

Edwin Sutherland melihat bahwa kejahatan muncul dalam sebuah proses belajar. Sekalipun terlihat sangat umum dan tidak bisa dipaksakan untuk menjelaskan semua bentuk kejahatan, akan tetapi teori Sutherland tentang Differential Association dengan 9 postulasinya terasa sangat logis dan cukup berhubungan. Hubungan belajar kejahatan dalam teori Sutherland, merupakan penjelasan hubungan kejahatan dalam konteks interaksi sosial saja dan tidak yang lain (Lilly, dkk : 2012).

Setidaknya terdapat 9 proposisi dari teori Sutherland menjelaskan hubungan terhadap perilaku kejahatan (dalam, Mustofa : 2010) diantaranya :

1. Tingkah laku jahat dipelajari.

2. Kejahatan dipelajari dalam proses komunikasi; 
3. Belajar kejahatan terjadi dalam hubungan kelompok yang akrab;

4. Belajar kejahatan meliputi; teknik melakukan kejahatan, motivasi yang khas, dorongan, rasionalisasi, dan sikap;

5. Motivasi yang khas, dan dorongan dipelajari ketika individu-individu tadi dihadapkan pada aturan tingkah laku tunduk hukum yang harus ditaati maupun pada aturan tingkah laku yang lebih condong dengan pelanggaran hukum;

6. Seseorang menjadi delikuen lebih dipengaruhi pada perhatian yang lebih condong pada pelanggaran hukum

7. Tindakan delikuen tergantung pada frekuensi, lamanya, prioritasnya, dan intensitasnya dengan aturan tingkah laku yang bersangkutan;

8. Dalam mempelajari tingkah laku tersebut dilakukan melalui mekanisme yang dibutuhkan dalam belajar tingkah laku apa saja;

9. Tingkah laku jahat dan tingkah laku tidak jahat tidak dapat dibedakan berdasarkan kebutuhan umum dan nilai-nilai umum, karena kedua bentuk tingkah laku yang bertentangan tersebut merupakan ekspresi yang sama atas kebutuhan umum dan nilai-nilai umum.

\section{b. Imitation Process / Proses Peniruan.}

Imitation Process yang dijelaskan Gabriel dalam melakukan kejahatan, bahwa sesorang menentukan pilihan mencontoh atau meniru dikarenakan pertimbangan kegunaan serta kebaikan untuk dilakukan, sehingga perlu menginternalisasikan diri melalui imitasi. Lebih lanjut Gabriel Tarde, pengamatan seseorang terhadap tingkah laku orangorang dilingkungannya menjadi inspirasi untuk ditiru (Scott : 2012).

\section{c. Techniques of Neutralization / Teknik Netralisasi}

Tindakan penyimpangan merupakan perbuatan yang tidak saja dilakukan oleh mereka yang anti terhadap aturan sosial, namun juga mereka yang mendukung terhadap aturan dan nilai sosial (Ward : 1994).

Esensi teori Sykes \& Matza ini, bahwa netralisasi tindakan penyimpangan, lebih dulu hadir sebelum tindakan tersebut dilakukan oleh pelaku (Ward : 1994)

Dalam konteks teori ini, pelaku akan melakukan pembenaran dengan merasionalisasikan tindakannya sebagai upaya untuk tidak dapat dipersalahkan. Situasi ini juga berkaitan dengan kondisi dimana aturan yang ada berlaku sangat pleksibel dan longgar, tidak mengikat dalam semua situasi (Williams : 1951). 
Terdapat beberapa faktor dari merasionalisasikan tindakan penyimpangan menurut Sykes \& Matza (Wolfgang : 1970) :

1. Pengalihan tanggung jawab atas tindakan yang dilakukan karena merasa diri sebagai korban.

2. Tindakan yang dilakukan dianggap sebagai bentuk pembalasan.

3. Kemampuan membandingbandingkan dengan kesalahan orang lain.

4. Lebih berorientasi kepada nilai dan kebiasaan sesamanya, serta cenderung enggan untuk memikirkan orang lain.

\section{Metode Penelitian}

\section{a. Tipe Penelitian}

Penelitian ini menggunakan pendekatan kualitatif. Penelitian kualitatif sendiri berusaha memahami makna dari suatu kejadian dan interaksi dari orangorang pada situasi tertentu (Bungin : 2011). Dengan menggali makna dari setiap orang yang dilibatkan dalam penelitian ini, maka akan didapatkan gambaran yang utuh yang menjadi masalah dalam penelitian ini.

\section{b. Tempat Penelitian}

Lokasi penelitian berada di Desa Belilas, Kecamatan Seberida, Kabupaten Indragiri Hulu (Riau). Ada beberapa alasan dijadikannya daerah ini sebagai tempat penelitian diantaranya :

1. Ditemukannya fenomena penyalahgunaan obat batuk aditusin dominan oleh anak-anak remaja.

2. Ditemukannya kemasan obat batuk aditusin yang berbentuk tablet maupun box dibeberapa lokasi di tempat-tempat yang biasa digunakan sebagai tempat berkumpul anak-nak remaja.

3. Karena belum adanya penanganan yang memadai mengenai kasus menyimpang ini dari aparatur daerah setempat.

\section{c. Subjek Penelitian}

Subjek utama dalam penelitian ini adalah 4 (empat) orang remaja pengguna obat batuk aditusin. Ke 4 (empat) remaja dijadikan sampel mewakili rekan-rekan sebayanya atas dasar pertimbangan;

1. Kecakapan dalam menanggapi pertanyaan

2. Keterbukaan dalam berbagi cerita dan pengalaman.

Disamping subjek utama di atas, masih terdapat juga subjek-subjek lain seperti; Kepala Desa, Babinkantibmas serta perwakilan Masyarakat. 


\section{Pembahasan}

\section{a. Persepsi}

\section{Remaja}

\section{Terhadap}

\section{Penyalahgunaan Obat Batuk}

Aditusin.

Obat batuk aditusin sebagai jenis obat yang legal dengan harga yang relatif murah serta mudah untuk didapatkan di tempat-tempat penjualan obat (apotik) maupun di warung-warung, merupakan fakta yang difahami oleh para remaja pengguna. Masing-masing mereka dapat membedakan dengan baik antara obat batuk aditusin yang mereka konsumsi dengan obat-obatan terlarang seperti; sabusabu, ganja dan sebagainya beserta segala konsekuensinya baik sosial maupun hukum.

...aditusin ni kan obat
batuk bang, banyak kok
bebas sapa aja bisa beli
ga da masalah.., tapi
macem sabu, ganja, kan
dilarang, bahayalah bisa
kenak polisi...(hasil
wawancara dengan
informen inisial Ad 19
th).

...kalau narkoba ya kayak sabu-sabu tu.., kalau inikan obat biasa obat batuk, boleh gak ada yang larang...(hasil

wawancara dengan informen inisial $\mathrm{Gn} 18$

th).

Kesadaran akan dampak buruk (overdosis) dari penggunaan obat batuk aditusin tersebut nyaris tidak mereka pikirkan mengingat apa yang mereka yakini hanyalah sebatas obat batuk saja. Berbeda dengan narkoba yang mereka anggap berbahaya dan dilarang oleh hukum, yang secara otomatis akan berhadapan dengan aparat hukum (kepolisian) bagi yang tertangkap. Alasan ketiadaan larangan baik dari sisi hukum maupun lingkungan sosialnya tersebut, menjadi pertimbangan utama bagi mereka merasa lepas dari kesalahan. Mengutip pendapat Williams (1951), hadirnya situasi longgar atau fleksibelnya aturan-aturan yang ada menjadi situasi pendorong munculnya penyimpangan.

\section{b. Proses Pemakaian Obat Batuk Aditusin.}

Secara umum penggunaan obat batuk oleh masyarakat adalah disaat terjadinya gangguan kesehatan (batuk). Namun hal yang tak lazim dilakukan oleh remaja penyalahguna obat batuk aditusin, mereka menggunakannya untuk kepentingan mendapatkan sensasi mabuk atau nge-flay dari pemakaian secara 
berlebih. Pemahaman awal tentang efek yang dapat ditimbulkan (nge-flay) dari obat batuk aditusin, tidak lepas dari hubungan pertemanan dan masih ada hubung- kait dengan riwayat pemakaian narkoba sebelumnya.

...kalau aku dapet info dari kawan-kawan biasa nongkrong di luar bang...cobak-cobak lumayan jugak.. dapet jugak rasanya, hehe... lebih aman.., ketimbang sabu, resiko besar bang... (hasil wawancara dengan informen inisial Ad 19 th).

...gak pernah bang aku, kalo nyabu, takut lah...kalo obat batuk ini ya dikasi tau anak-anak tu...kalo lagi ngumpul suntuk-suntuk ya tinggal beli...ya asik jugak bang flay bawaannya...(hasil wawancara dengan informen inisial Dd 17 th).

Kreatifitas menggunakan obat batuk aditusin oleh mereka selaku pengguna di daerah dimana mereka tinggal (Desa Seberida), menginspirasi dari pengguna aditusin yang ada sebelumnya melalui komunikasi pertemanan dengan mereka yang berada di luar daerahnya. Hal ini menunjukkan jika hubungan komunikasi diantara sesama pengguna itu terjadi tidak hanya sesama pertemanan di satu tempat (daerah), melainkan lintas tempat atau daerah. Ikatan emosional (feargroup) inilah yang sebenarnya melanggengkan proses pengetahuan dari masing-masing mereka (menjangkau wilayah per wilayah) terhadap fungsi obat batuk aditusin dapat digunakan untuk kepentingan mabuk atau nge-flay. Dalam hal ini bentuk pengulangan perilaku, meniru penyalahgunaan obat batuk aditusin dari yang sudah ada sebelumnya di daerah lain telah terjadi. Tepat seperti yang dikatakan Gabriel Tarde, pengamatan seseorang terhadap tindakan sosial dalam lingkungannya secara naluriah akan menjadi inspirasi untuk ditiru.

Peniruan tersebut tidakhanya menyangkut jenis obat batuk yang dikonsumsi saja, tentu lengkap dengan setiap konsekuensinya utamanya terkait dengan cara mengkonsumsinya. Dalam hal menggunakan aditusin untuk dapat mabuk dan nge-flay, pengguna harus mencampurkan sejumlah butiran tablet aditusin dengan melarutkannya kedalam cairan minuman seperti Sprite atau Terpedo. 
...makek nya dicampur

sprite bang..., cepet

nendangnya. Terpedo

bisa jugak.. (hasil

wawancara dengan

informen inisial Dd 17

th).

Pilihan campuran cairan sprite maupun terpedo untuk pelarutan, turut menentukan percepatan pengaruh reaksi (nge-flay) yang diinginkan dari mengkonsumsi obat batuk aditusin tersebut. Inilah sebagai proses belajar seperti yang dikatakan Sutherland, bahwa seseorang belajar tingkah laku jahat itu meliputi; cara dan taktik, motivasi serta rasionalisasi (Mustofa : 2010).

\section{c. Persepsi Remaja Penyalahgunaan Obat Batuk Aditusin Terhadap Lingkungan Sosial}

Berbeda dengan narkoba seperti sabu-sabu, ganja, inek dan seterusnya, secara umum dari namanya saja semua orang tau jika jenis zat-zat itu berbahaya dan terlarang. Sementara obat batuk aditusin, tidak diketahui oleh banyak orang jika dapat digunakan secara salah sebagai pengganti obat-obatan terlarang. Hanya sebagian dari kalangan muda saja diluar pengguna yang mengetahui hal itu. Untuk kalangan orang tua, nyaris tidak tau tentang fenomena dapat

disalahgunakannya obat batuk tersebut. Kalaupun ada kecurigaan dari bagian anggota masyarakat, diantaranya dari para penjual obat aditusin baik pemilik warungwarung maupun pihak apotik, serta sedikit dari orang-orang dewasa (mahasiswa di Desa itu) yang memang mempunyai kepedulian terhadap persoalan anak-nak remaja. Kesan-kesan kecurigaan biasanya muncul dari para penjual obat batuk aditusin, baik pemilik warung maupun penjual obat di apotik dalam bentuk pertanyaan-pertanyaan bernada menelisik, mengingat seringnya diantara remaja pengguna membeli obat batuk aditusin dalam jumlah yang banyak ditempattempat itu. Namun hal ini tetap tidak menghalangi remaja pengguna untuk dapat membeli obat batuk tersebut.

...ga da yang tau,..
orang-orang tua ga tau
lah, rang cuma obat
batuk kok...paling ya
anak-anak lain yang ga
makek ada jugak yang
tau,.. trus orang-orang
kede sama apotik
palingan, agak sukak
tanyak-tanyak gitu aja...
(hasil wawancara
dengan informen inisial
Rn 18 th).


Kecurigaan lain juga datang dari bagian kecil anggota masyarakat dewasa seperti mahasiswa dari Desa itu, yang dalam sekali dua kali kasus pernah menemukan kemasan obat batuk aditusin berserakan di tempat dimana para remaja berkumpul. Temuan serakan kemasan obat batuk aditusin yang dianggap tak biasa tersebut membuat para remaja pengguna mendapati teguran keras bahkan ancaman laporan kepada RT dan Polisi setempat.

...pernah sama abang-
abang kuliahan...nampak
sampah bungkus-
bungkus obat, marah-
marah dia mau laporkan
ke RT ma Polisi... (hasil
wawancara dengan
informen inisial Dd 17
th).

Sayangnya, reaksi serupa seperti yang dilakukan mahasiswa tersebut tidak diikuti oleh lapisan masyarakat lainnya di Desa itu. Sehingga realita penggunaan obat batuk aditusin secara salah dilakukan oleh anak-anak remaja terbiarkan berlanjut tanpa adan intervensi seakan tanpa ada masalah. Kondisi ini semakin membuat para remaja pengguna langgeng dan bebas melakukan kebiasaannya, hingga pada akhirnya mereka merasa tidak ada satu pihakpun yang dirugikan dalam masalah itu.

\author{
...tapikan bukan narkoba \\ bang...narkoba ya lah, \\ rusuh-rusuh rang tu, \\ paksa ncuri kerjaannya, \\ kalo ga ga bisa makek... \\ (hasil wawancara \\ dengan informen inisial \\ Rn 18 th).
}

Argumentasi pembenaran atau tak ingin dipersalahkan dari tindakan menyimpang yang biasa mereka lakukan dari penggunaan obat batuk aditusin, menjadi semakin terang disaat mereka mampu membuat perbandingan terhadap kesalahan orang lain dalam kasus pemakaian narkoba, yang terpaksa harus mencuri (perhitungan biaya mahal) hingga merugikan banyak orang. Bila dicermati fakta pernyataan dari remaja pengguna, tentu cukup menarik dihubungkan dengan apa yang dikatakan Sykes \& Matza menyangkut the condemnation of the condemners; dimana pelaku justru malah membanding-bandingkan perbuatannya dengan kesalahan yang orang lain lakukan, dengan begitu, pelaku berharap perhatian atas perbuatannya dapat teralihkan (Wolfgang : 1970).

\section{Kesimpulan}

Dari temuan penelitian yang telah dipaparkan, maka dapat disimpulkan; 
bahwa penyalahgunaan obat batuk aditusin oleh remaja di Desa Belilas, Kec. Seberida, Kab. Inhu (Riau), adalah wujud peralihan dari penggunaan obat-obatan terlarang seperti sabu-sabu, ganja dll, dengan reaksi efek yang relatif sama (ngeflay). Pilihan ini berangkat dari rasionalisasi resiko (jeratan hukum dan reaksi sosial), harga (murah) dan kemudahan dalam mendapatkannya. Fakta ini semakin mengkhawatirkan disaat para pengguna dapat menjustifikasi (pembenaran) tindakan dari penyalahgunaan obat batuk aditusin tersebut bukan merupakan jenis obatobatan terlarang, sekaligus dianggap tidak merugikan orang lain.

\section{Saran}

Mencermati hasil penelitian yang telah dikemukakan di atas, maka diperlukan langkah penyelamatan menghindarkan remaja dari penyalahgunaan obat-obatan diantaranya :

1. Pemerintah melalui BPOM perlu melakukan pengawasan ketat terhadap peredaran obat-obatan legal (diperjualbelikan) yang potensial dapat disalahgunakan oleh siapapun.

2. Diperlukan aturan hukum bersifat mengikat (pidana) terhadap penyalahgunaan obat-obatan legal diluar kepentingan kesehatan.

3. Diperlukan partisipasi aktif masyarakat peduli terhadap tingkah laku menyimpang remaja dalam bentuk apapun demi upaya menyelamatkan generasi muda. 


\section{Daftar Pustaka}

Bungin, Burhan. 2011. Penelitian

Kualitatif. Jakarta: Kencana

Predana Media.

Mustofa, Muhammad. 2010. Kriminologi:

Kajian Sosiologi Terhadap

Kriminalitas,

Perilaku

Menyimpang dan Pelanggaran

Hukum. Bekasi: Sari Ilmu

Pratama.

Prayuda, Rendi \& Syafri Harto. 2020.

ASEAN \& Kejahatan

Transnasional Narkotik

(Problematika, Dinamika dan

Tantangan). Yogyakarta: Ombak

Tiga.

Scott. J. 2012. Teori Sosial : Masalahmasalah Pokok dalam Sosiologi. Yogyakarta: Pustaka Pelajar.

Ward, David A, et. all. 1994. Social Deviance: Being, Behaving, and Branding. Allyn and Bacon:
Boston London Toronto Sydney Tokyo Singapore.

Williams, Robin Jr. 1951. American Society. Knopf: New York.

Wolfgang, Marvin. Et. Al. 1970. The Sociology of Crime and Delinquency. (Second Edition). Jhon Wiley and Sons, Inc.

Peraturan BPOM RI nomor 28 tahun 2018 tentang Pedoman Pengelolaan Obat-Obat Tertentu yang Sering Disalahgunakan.

https://www.cnnindonesia.com/nasional/2 0190622182557-20405549/survei-bnn-23-jutapelajar-konsumsi-narkoba.

https://www.sehatq.com/artikel/dextromet horphan-hbr-obat-batuk-yangsering-disalahgunakan.

https://www.klikdokter.com/obat/aditusin. 